論文

\title{
経年劣化や人的過誤等を含めた原子力発電所不具合事象の 新たな原因分類法とその適用結果
}

\author{
宮崎 孝正 ${ }^{1, *}$ \\ Development of a New Cause Classification Method Considering Plant Ageing and Human Errors for \\ Adverse Events Which Occurred in Nuclear Power Plants and Some Results of Its Application \\ Takamasa MIYAZAKI ${ }^{1 *}$ \\ ${ }^{1}$ Institute of Nuclear Safety System, 64 Sata, Mihama-cho, Mikata-gun, Fukui 919-1205, Japan
}

(Received January 19, 2007 and accepted in revised form July 23, 2007)

\begin{abstract}
The adverse events which occurred in nuclear power plants are analyzed to prevent similar events, and in the analysis of each event, the cause of the event is classified by a cause classification method. This paper shows a new cause classification method which is improved in several points as follows: (1) the whole causes are systematically classified into three major categories such as machine system, operation system and plant outside causes, (2) the causes of the operation system are classified into several management errors normally performed in a nuclear power plant, (3) the content of ageing is defined in detail for their further analysis, (4) human errors are divided and defined by the error stage, (5) human errors can be related to background factors, and so on. This new method is applied to the adverse events which occurred in domestic and overseas nuclear power plants in 2005. From these results, it is clarified that operation system errors account for about $60 \%$ of the whole causes, of which approximately $60 \%$ are maintenance errors, about $40 \%$ are worker's human errors, and that the prevention of maintenance errors, especially worker's human errors is crucial.
\end{abstract}

KEYWORDS: nuclear power plant, trouble, adverse event, accident and incident, ageing, human error, cause classification, tendency analysis

\section{I. 緒 言}

他の原子力発電所で発生した不具合事象 (事故・故障や 軽微な事象など正常ではない事象全体を指す。以下，不具 合という) から教訓を抽出し，同種・類似の不具合発生を 未然防止する不具合反映活動が国内外の原子力発電所や関 係諸機関で積極的に進められている。この不具合反映のた めの分析方法としては，1) 個々の不具合の原因や対策の 内容を質的に分析して同種・類似の不具合発生防止のため の改善点を抽出する個別分析と，2）多くの不具合全体を 量的に統計分析して不具合の発生傾向や共通要因等を抽出 する傾向分析の 2 種類がある。

㧣原子力安全システム研究所 (Institute of Nuclear Safety System, Incorporated，以下，INSS という)では，原子 力発電所の安全性と信頼性の向上を図るため, 海外の原子

\footnotetext{
1 秼原子力安全システム研究所

* Corresponding author, E-mail: miyazaki@inss.co.jp

(C)Atomic Energy Society of Japan
}

力発電所の不具合情報を收集し，これらを個別分析して国 内加圧水型 $(\mathrm{PWR})$ 発電所への改善提言を行うとともに, 個々の不具合の運転状態, 不具合原因, 不具合発生機器, 不具合による影響，対策，等を分類コード付けしてデータ ベース化し，不具合発生の傾向分析 ${ }^{1 \sim 4)}$ を行うなどの不具 合反映活動を行っている。

不具合の原因分類は，傾向分析を行う際には特に重要な 分析因子であり，原因分類した結果から検討の方向性や対 策の対象などが浮き彫りになることが望ましい。しかしな がら, 原子力発電所の不具合に関する世界的に標準とされ る原因分類法というのはなく，国内では経済産業省原子力 安全・保安院が電気保安年報へ掲載する電気事故の原因分 類法5)を定めており，国への報告書や日本原子力技術協会 の原子力施設情報公開ライブラリー (ニューシア $)^{6)}$ に掲載 されている不具合の原因分類に適用されている。海外では 世界原子力発電事業者協会 (World Association of Nuclear Operators, WANO)が独自の原因分類法を採用しているが 公表されていない。米国ではNRC が発行した報告書7に 
原子炉トリップ起因事象に関わる原因分類を扱った特定の 分類法があるが不具合全般を扱った原因分類法はない。ま た，国際原子力機関 (IAEA) も原因分類法を作成してはい ない。このように，原子力発電所の不具合の原因分類につ いては，原子力安全の向上をねらいにしていながらも，そ れぞれの機関や団体がそれぞれの目的に合わせて独自の原 因分類法を作成し使っているのが現状であり，INSSでも これまで独自の原因分類法を採用していた。これらの原因 分類のうち，ニューシアやWANO のように不具合反映を 目的とした国内外の原因分類法をみてみると，既存の国内 の原因分類法では「経年劣化」や「運転不良」に該当する 項目がなく不具合の実態と整合してない，海外の原因分類 法では分類項目の独立性・網羅性・細か過ぎる，等の問題 がある。また，これまでのINSS の原因分類にも「経年劣 化」がなかった。このように，これまでのものはいずれも 実務的・体系的に原因分類して傾向分析を行うには不十分 で利用し難い点があった。そこで，従来の原因分類法を見 直して，1)「経年劣化」分類項目の設定，2)発電所の保安 管理の実態に合わせた分類項目の設定，3)人的過誤の分 類項目の明確化，4）人的過誤とその背後要因との因果関 係を付けられる分類体系，等の改善を図るとともに，不具 合原因を設備面(機械系) と運用面 (人間系)の両方の観点か ら体系的に分類する新しい原因分類法を考案した。

INSS ではこの新原因分類法を2006年から正式適用して いるが，経年劣化の不具合抽出が容易になった。また， 2005 年に入手した国内外の不具合情報に適用して傾向分 析することにより，運用面の不具合，特に保守不良におけ る人的過誤の多いことが判明するなど，不具合の特徵を浮 かび上がらせることが可能となった。

本研究では，新しく考案した原因分類法の内容とこれを 適用した最近の傾向分析の結果について述べる。

\section{II. 不具合反映活動の現状}

\section{1. 不具合の報告状況と分析状況}

国内では，2004年に電気事業連合会の中にPWR 海外 情報検討会と BWR 海外情報検討会が設立され，海外の原 子力発電所で発生した不具合から国内に反映すべき点の検 討が行われており，INSS は PWR 海外情報検討会の事務 局として活動している。

国内の原子力発電所で発生した不具合のうち法律および 通達対象として国へ報告された不具合は，原子力安全・保 安院からプレス発表されるとともに原子力施設運転管理年 報8) や原子力安全基盤機構のトラブル情報データベース ${ }^{9)}$ にも揭載され公開されている。また，2004年からは，二 ューシアに軽微な不具合も加えて揭載され公表されている。

海外で発生した不具合は，インターネット上で，国際原 子力機関 (IAEA)，米国の原子力規制委員会 (Nuclear Regulatory Commission, NRC)，仏国の原子力安全規制当 局(Autorite de Surete Nucleaire, ASN)から公開されてい

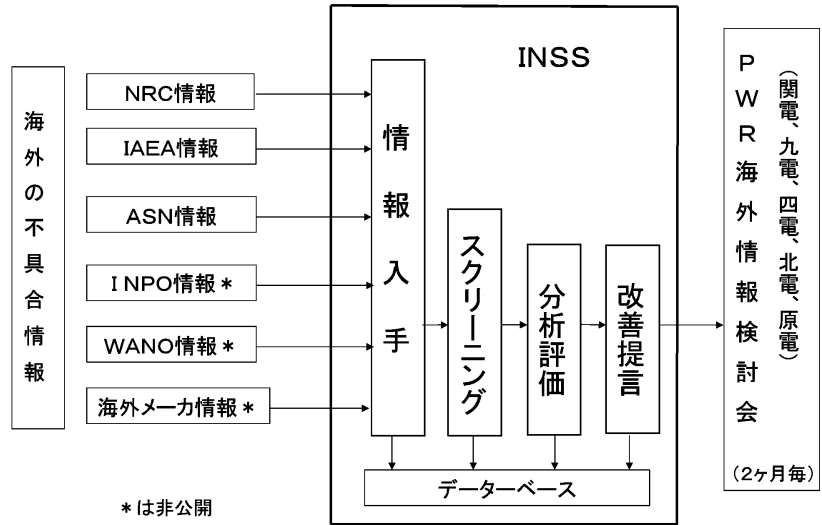

第 1 図 海外不具合情報の入手·分析の流れ

第 1 表 安全性と信頼性の内容

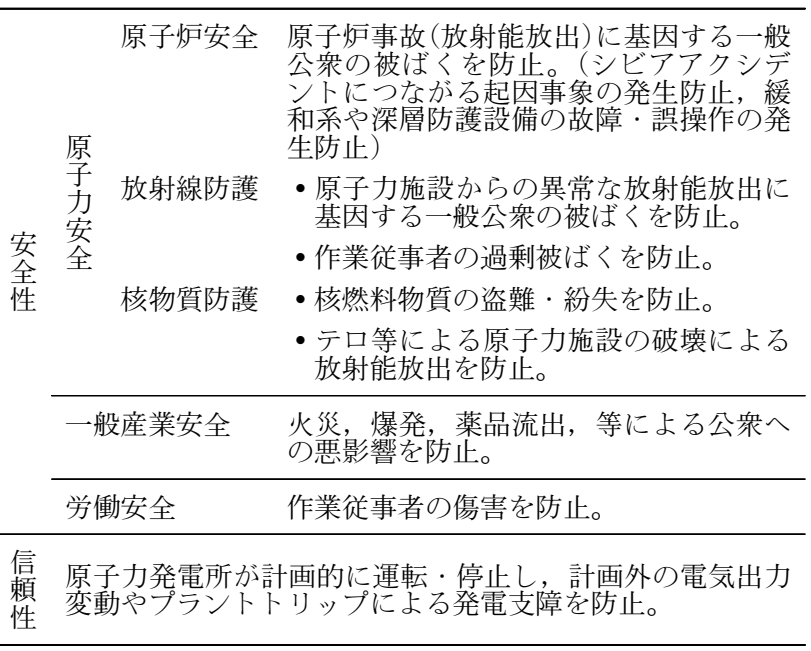

る。その他, 原子力発電運転協会 (Institute of Nuclear Power Operations, INPO) やWANO からも会員（原子力 発電事業者) 向けに不具合情報 (非公開) が報告されてお り，海外原子力発電メーカからも不具合情報(非公開)が報 告されている。これら国内外で報告されている不具合の大 部分は国際原子力事象評価尺度 (INES) ゼロ以下の軽微な 不具合である。

INSS では，第 1 図に示すように，これらの海外不具合 情報を毎年約 3,000 件入手し，第 1 表に示す安全性と信頼 性の観点から分析評価して，抽出した10件程度の改善案 を前述の委員会を通じて国内 PWR 電力会社 (5 社)に提言 している。また，様々な機器を対象にした傾向分析を行 い，抽出された不具合の発生傾向を電力会社や学会に報 告1 4) している。

\section{2. 既存の原因分類法の問題点}

国内の不具合は，前項 II-1 節で述べたように，各種の 機関から公表されるとともにデータベース化も図られてい るが，原因分類法を公表している所は少ない。既存の国内 外の原因分類法で原子力発電所の不具合の傾向分析を行う 
には次のような問題点がある。

\section{（1）電気保安年報の原因分類法の問題点}

原子力安全・保安院が定めている電気保安年報の原因分 類法を第 2 表に示すが，電気関係の事故を収集し分類す る目的で設定されているため，原子力発電所の不具合原因 に適用するには不都合な点がある。例えば，「設備不備」 に設計不良の分類項目がない，「運転不良」の分類項目が なくて人的過誤の面から類似項目である「作業者の過失」 に分類すると「保守不良」との区分ができなくなる，「保 守不備」の内訳に「自然劣化」が整理されているが「腐食」 は「保守不備」と同列で扱われているなど「経年劣化」と してまとめて分類されてない，「然料不良」が特別に項目 出しされている，等，分類項目の独立性や網羅性の点で問 題があり，原子力発電所の実態的な原因分類としては利用 し難い。

\section{（2）海外の原因分類法の問題点}

公開されている海外の原子力発電所の不具合原因分類 法6)では，分類項目の独立性と網羅性が不十分で体系的な 分類法がない。非公開のWANO の原因分類法は人的過䛊 の分類項目が細分化され過ぎており実務面からは使い難い 点がある。

（3）INSS の旧原因分類法の問題点

INSS の旧分類法は, 電力中央研究所 (旧原子力情報セ

第 2 表 電気保安年報の原因分類表 1

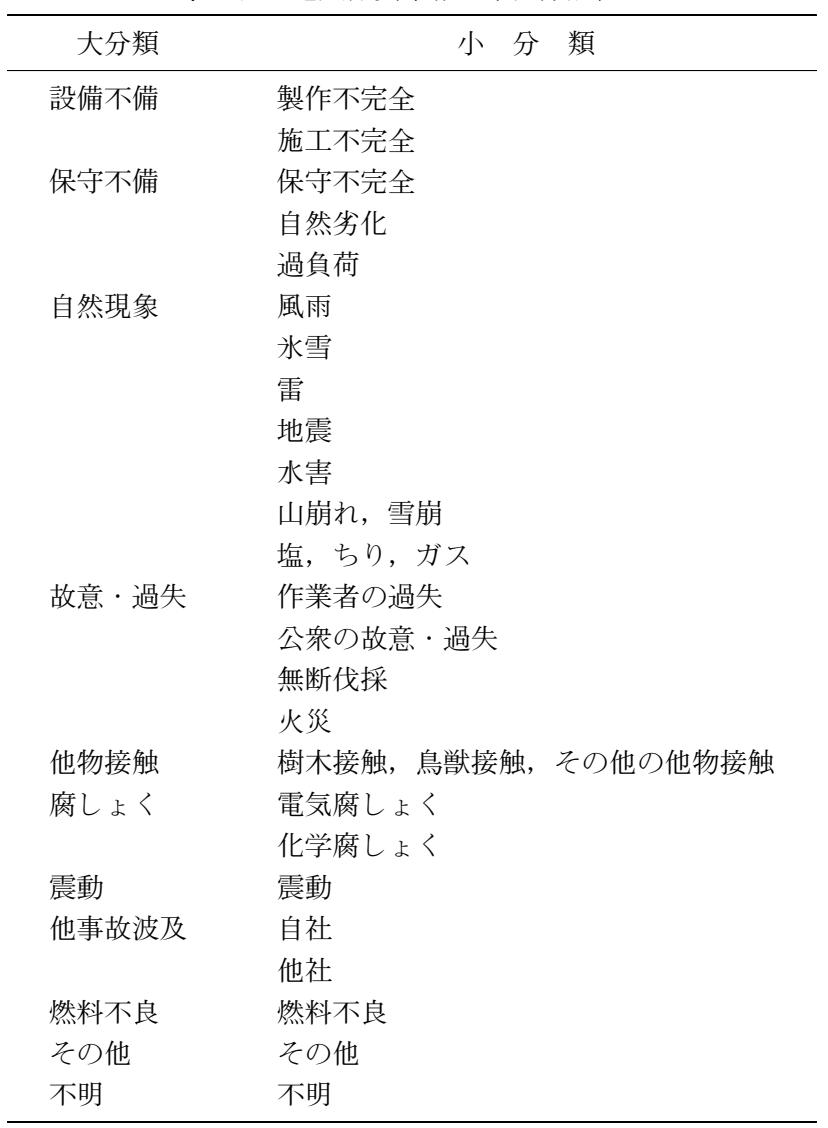

(ニューシア揭載の国内原子力発電所不具合の原因分類でも準用)
ンター)が使用していた原因分類法に準拠した原因分類法 であったが，この分類法には次のような問題点があり，こ の原因分類法で分類された結果は傾向分析等にはあまり活 用されていなかった。

(a) 2004年 8 月に発生した関西電力美浜 3 号機事故の 直接原因が経年劣化による 2 次系配管破断であった ことや，国内外の多くの原子力発電所が運転期間30 年を越えつつあることから経年劣化に対する関心が高 まっているが，「経年劣化」の分類項目がない。

(b) 美浜 3 号機事故のもう 1 つの原因としてその破断 箇所が長年検査対象から洩れていたという品質管理シ ステムの不良があるが，組織要因のもととなる個人の 人的過誤を分析できる分類体系とはなって抢らず，人 的過誤に相当する分類項目の定義も明確でなかった。

(c) 設備不良または設備劣化の一部であるべき「疲労損 傷」が設備不良や設備劣化と同列に扱われており，分 類項目の独立性や体系が十分に考慮されていなかった。

(d) 管理不良の定義が不明確であり，人的過䛊との関係 が明確に整理されてなかった。

\section{III. 新原因分類法}

\section{1. 新原因分類法とその構成}

新原因分類表を第 3 表に示すが，原因を大分類・中分 類·小分類に展開する体系とした。大分類は，発電所の内 部要因である「設備」と「運用」に，「外部要因」を加え た 3 分類とした。中分類は，一般に用いられる分類項目 に相当し，設備面は「設計不良」·「製造不良」·「施工不 良」·「経年劣化」·「偶発故障」の 5 分類とし，運用面は 各種管理のうち不具合発生の多い運転管理と保守管理の不 良である「運転不良」・保守不良」と不具合の少ない燃料 管理等をまとめた「その他の管理不良」の 3 分類とした。 小分類は中分類の各項目をそれぞれ展開したものである が，「設備」の中にも小分類項目として，人的過誤である 「設計者過䛊」，「製造者過䛊」，「施工者過䛊」を新たに設 定するとともに，不可抗力的なものは「軽微想定外不良」 として区分した。一方，「運用」の中分類のうち「運転不 良」と「保守不良」は，人的過誤を「操作者過䛊」と「作 業者過誤」とし，その背後要因となり得る「計画不良」· 「周辺状況不良 (機器·工具不備, 作業環境不備, 指示·連 絡不備）」を分類項目として設定して置くことにより，人 的過誤と背後要因の相関関係が必要なときに分析しやすい 体系とした。

「外部要因」は, 発生数も少ないことから, 自然現象 (地 震，雷，等)や送電線系統事故を対象とした「想定内不良」 と，テロ等の破壊工作を対象とした「想定外不良」の 2 分類とした。

なお，不具合報告書には原因不明や記載がない報告書も あるので，「不明」の分類項目も必要であるが，分類表(第 3 表)ではこれを省略している。 
第 3 表 新原因分類表

\begin{tabular}{|c|c|c|}
\hline 大分類 & 中分類 & 分 \\
\hline \multirow[t]{6}{*}{ 設備 } & 設計不良 & $\begin{array}{l}\text { 設計時の基準・規格・仕様書の不備 } \\
\text { 設計者過誤(設計時の個人要因による人的 } \\
\text { 過誤) } \\
\text { 現時点の基準に照らして不十分な設計 } \\
\text { その他 }\end{array}$ \\
\hline & 製造不良 & 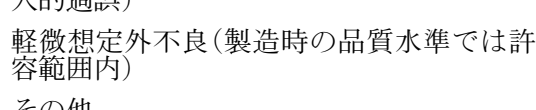 \\
\hline & 施工不良 & $\begin{array}{l}\text { 施工者過誤 (発電所建設時の個人要因によ } \\
\text { る人的過誤) }\end{array}$ \\
\hline & & $\begin{array}{l}\text { 軽微想定外不良(建設時の品質水準では許 } \\
\text { 範囲内) }\end{array}$ \\
\hline & 経年劣化 & $\begin{array}{l}\text { 機械設備・電気設備の経年劣化(別表参照) } \\
\text { コンクリート部の経年劣化(別表参照) } \\
\text { 原因不特定 }\end{array}$ \\
\hline & 偶発故障 & $\begin{array}{l}\text { 機器の偶発故障 (耐用年数内のランダム故 } \\
\text { 障) }\end{array}$ \\
\hline \multirow[t]{17}{*}{ 運用 } & 運転不良 & $\begin{array}{l}\text { 計画不良 }(\text { 要領書·運転手順書などの不備 } \\
\text { による操作不良) }\end{array}$ \\
\hline & & $\begin{array}{l}\text { 操作者過誤 (運転操作時の個人要因による } \\
\text { 人的過誤) }\end{array}$ \\
\hline & & $\begin{array}{l}\text { 周辺状況不良 (機器. 工具不備, 環境不備, } \\
\text { 指示·連絡者の不備, 等による連転不良) }\end{array}$ \\
\hline & & $\begin{array}{l}\text { 軽徽想定外不良(想定外事象への対応不十 } \\
\text { 分連軺果) }\end{array}$ \\
\hline & & その他 \\
\hline & 保守不良 & $\begin{array}{l}\text { 計画不良 (要領書・作業手順書などの不備 } \\
\text { による作業不良) }\end{array}$ \\
\hline & & $\begin{array}{l}\text { 作業者過誤 (保守作業時の個人要因による } \\
\text { 人的過誤) }\end{array}$ \\
\hline & & $\begin{array}{l}\text { 周辺状況不良 (機器. 工具不備, 環境不備, } \\
\text { 指示·連絡者の不備, 等による作業不良) }\end{array}$ \\
\hline & & $\begin{array}{l}\text { 軽微想定外不良 (予見不可事象, 検査合格 } \\
\text { た质, 疵等) } \\
\text { その他 }\end{array}$ \\
\hline & $\begin{array}{l}\text { その他の } \\
\text { 管理不良 }\end{array}$ & $\begin{array}{l}\text { 然料管理不良(第 } 4 \text { 表に示す管理内容の不 } \\
\text { 備) }\end{array}$ \\
\hline & & 放射線管理不良(同上) \\
\hline & & 廃棄物管理不良(同上) \\
\hline & & 水質管理不良 （同上） \\
\hline & & 性能管理不良 （同上） \\
\hline & & 防災管理不良 （同上） \\
\hline & & 出入管理不良 （同上） \\
\hline & & 方針管理不良 （同上） \\
\hline
\end{tabular}

外部要因 外部要因 想定内(地震・雷・送電線事故などによる 機器損傷)

想定外 (妨害行為・テロによる機器損傷)

\section{2. 新原因分類法での考慮点と特長}

新原因分類法は，II-2 節に示した国内外および INSS の 様々な問題点を包括的に解決して分析しやすくするととも に原子力発電所の不具合発生状況を体系的に診断しやすく した。以下に新分類法で考慮した点と特長を示す。

\section{(1) 発電所の管理者の視点に立った分類}

原因分類法を利用する立場からは，どのような視点で原
(別表)

\begin{tabular}{|c|c|}
\hline 小分類 & 具体的な不具合原因 \\
\hline $\begin{array}{l}\text { 機械設備· } \\
\text { 電気設の } \\
\text { 経年劣化 }\end{array}$ & 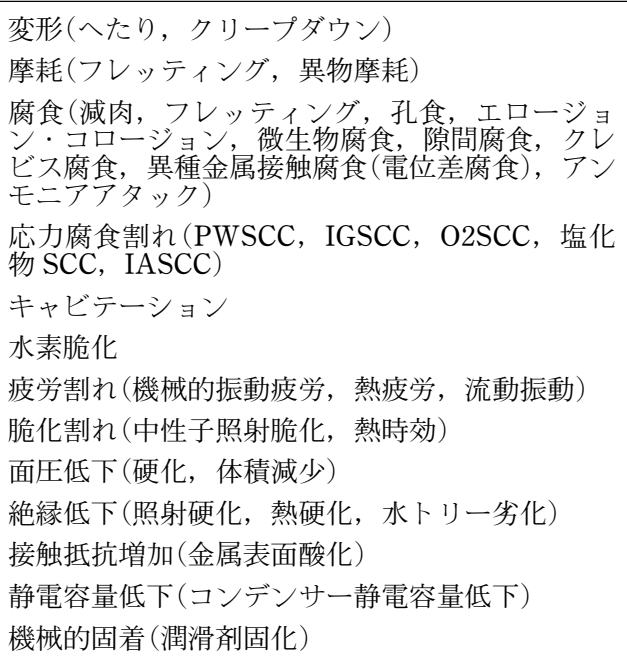 \\
\hline $\begin{array}{l}\text { コンクリー } \\
\text { 卜部の経年 } \\
\text { 劣化 }\end{array}$ & $\begin{array}{l}\text { 強度低下 (熱·放射線照射) } \\
\text { ひび割れ (中性化, 塩分浸透, アルカリ骨材反応) } \\
\text { 遮蔽能力低下(熱脱水) } \\
\text { 鉄骨腐食(酸素, 海水による腐食·強度低下) }\end{array}$ \\
\hline
\end{tabular}

因が分類されているのかは重要である。発電所の安全性は 建設前に発電所単位で安全審査され設置許可を受け, 建設 後も発電所単位で運転管理され，入手する不具合は供用中 原子力発電所で発生したものだけであること等から, 発電 所を運用管理する管理者(発電所長, 課長クラス)の視点に 立って原因分類する体系とし, 原因を発電所の内部要因 (設備面, 運用面) と外部要因に二分し, 発電所内で対処す る事項と発電所外で対処すべき事項を区分した。これによ り，対策措置を考える所管箇所が明確になる。

（２）発電所内の不具合を「設備」と「運用」に大別

発電所の安全性や信頼性は, 設備(機械系) と運用 (人間 系)の両面が縦系と横糸のように組み合わさって確保され るものであり，機械系と人間系のどちらに原因があるかを 判別できる分類体系とした。これにより, 改善を図る対象 が調達した設備か発電所内の運用かが判別され, 対策検討 の方向が判りやすくなる。

（3）設備面には「経年劣化」を設定

従来の分類法は, 建設時の設計不良や施工不良に重点が あり, 発電所供用後のことが十分に考慮されてないと考え られるので, 供用後に重要となる「経年劣化」の項目を設 定するとともに，ここに含まれるべき経年劣化事象を網羅 して第 3 表の別表のように明確に示した。なお, 分類項 目を細分化すると個々の不具合を原因分類してデータベー ス化する際に時間を費やすことになるので，分類内容は 第 3 表の別表のように細分化して示すが分類項目自体は 細分化せず経年劣化事象として抽出するの久とし, 後日詳 細分析が必要になったときに改めて詳細分類する考え方に した。 


\section{（4）運用面は各種管理で分類}

運用面の分類は, 保安規定に定める保安管理 (運転管 理, 保守管理, 燃料管理, 放射線管理, 廃棄物管理, 防災 管理)の管理項目や発電所で一般的に行われている管理項 目 (水質管理, 性能管理, 出入管理, 方針管理)で不具合を 分類することとして項目設定した。これら各種管理の内容 は一般的に第 4 表のように整理され, 発電所の管理者(発 電所長, 課長クラス)の管理単位にもなる。このように管 理単位で区分することによって, 発電所の品質確保のため の品質管理マネージメントシステムで改善措置を取るべき 所管箇所, どの品質管理マネージメントシステムの改善を

第 4 表 各種管理の内容

\begin{tabular}{|c|c|}
\hline 管理の種類 & 管 理 の 内 容 \\
\hline 個別 運転管理 & 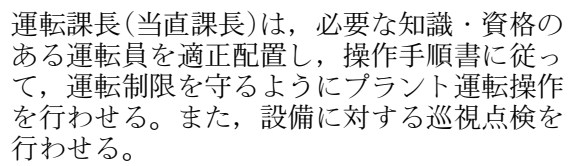 \\
\hline
\end{tabular}

保守管理設備の所管課長は, 必要な知識・資格のある 課員を適正配置し, 設備の保全計画(保守時 期, 保守方式, 保守内容, 要領書, 作業手順 書, 等) に従って設備の保守作業 (点検, 試 験, 補修(溶接, 等), 部品交換, 改造, 調 整, 検査, 等)を行わせる。

$(*)$ 保守作業は, 発電所内で行われる作業で, 直営作業と委託作業の両方を含む。

燃料管理 燃料課長は, 燃料課員に, 要領書に基づき, 燃料の受入, 保管, 炉心管理, 使用济燃料の 払出, 等を行わせる。

放射線管理 放射線管理課長は, 放射線管理課員に, 従事 者の被曝管理 (被曝量測定, 等), 発電所内作 業環境の)線量率管理(污染測定, 線量率測 定, 等), 放射線モニター(系統・環境の線量 率，等)を行わせる。

廃棄物管理 廃棄物管理の所管課長は, 課員に, 放射性廃 棄物 (気体, 液体) の外部放出量を基準内に管 理させる。また, 固体の放射性廃棄物を基準 (要領書)に従って保管させる。

水質管理 放射線管理課長は, 放射線管理課員に, 一次 系, 二次系の水質が基準 (要領書)に従ってい ることを確認させる。

性能管理 技術課長は, 技術課員に, プラントの電気出 力や熱出力等の性能が適正であることを確認 させる。

防災管理防災管理課長は，防災管理課員に，原子力㷋 害に備えた準備や㷋害時の対応を行わせる。

出入管理出入管理課長は, 課員に, 発電所構内や重要 施設内への物品や人の出入管理を行わせる。

方針管理 発電所長は, 発電所の基本的な運用方針を各 課長に示し，方針が守られていることを確認 する。

共通 人事管理 各課長は, 課員の能力を評価し, 人事異動に よる適正配置を図る。

教育管理 各課長は, 課員を教育・訓練し, 知識や技能 の維持と向上を図る。

労務管理各課長は, 就業規定に基づき, 課員の就業時 間, 休㗇, 等を適正に行う。をた, 労働安全 (労働災害の発生の可能性を検討し防止策を 講ずる)を図る。

品質管理 各課長は, 文書管理, 記録管理, 変更管理, 等を行う。
図ればよいかが明確になる。なお, 第 4 表で管理者の共 通管理項目も挙げているのは, 運用面の背後要因を詳細分 析する際の展開を考慮したものである。

この新分類体系では, 運転課長が管理すべき範囲での不 具合は「運転不良」, 保守課長など設備を所管する担当課 長が管理すべき範囲での不具合は「保守不良」として独立 させたが，その他の担当課長が管理すべき範囲の不具合は 発生数が少ないこともあり「その他の管理不良」にまとめ た。

実務上で明確にした点は, 供用中発電所で設備改造した 部分の不具合は, 調達管理上の不備は「保守不良」であり, 製造者の責任下の不良は「設計不良」か「製造不良」とし たことである。いい換えると,「保守不良」は発電所内で 不具合原因が発生した場合（保守員の直営作業とメ一カ・ 協力会社への委託作業の両方を含む)を指し, その原因が メーカ内や工場内で発生しておれば「設計不良」や「製造 不良」となる。

\section{（5）人的過誤を細分化して分類}

発電所の運用面だけでなく設備面の不具合（設計不良· 製造不良・施工不良) も人間が関与しており，設備の「経 年劣化」·偶発故障」を除くすべての不具合は人的過誤が 関連してくるので, 原因分類上では人的過誤を定義し区分 しておく必要がある。人的過䛊がどの段階の誰の過䛊であ るのかが判るように, 設計から運転・保守管理までの各中 分類項目に打ける人的過誤をそれぞれ「設計者過誤」，「製 造者過誤」,「施工者過誤」, 「操作者過誤」,「作業者過䛊」 として定義して明確に区分できるようにした点が特長であ る。例えば「保守不良」における「作業者過誤」は「保守 作業時の作業者の個人要因による人的過誤」と定義して他 の人的過䛊とを明確に区分できるようにした。ここで，個 人要因とは, 身体構造制限, 知覚力の限界, 記憶力の限 界, 慣れ ·習慣性 (スキーマ), 経験的思考(ヒューリステ イックス), 知識不足, 経験不足, 注意不足, 意欲低下, 思い込み, ストレス, 疲労, 等を指している。

個人要因に技量不足を含めると人的過誤の範囲が広くな り過ぎるという見方もあるが，部品取替間違いだけでなく 組立不良や調整不良も保守作業不良の要因となるので, 個 人の技量不足なども個人の判断行為の誤りの結果として扱 うこととした。

\section{（６）人的過誤の背後要因を分析できる体系}

人的過䛊は個人要因によってのみ発生するのではなく, 計画不良, 機器·工具不備, 作業環境不備, 上司·同僚の 指示・連絡不備, などが背後要因として影響しているとい われている。運転管理や保守管理における人的過誤は, 第 2 図に示すように, 背後要因も重複して抽出し関連付けて おくことにより, 人的過誤と背後要因との因果関係を分析 できるようにした。なお，背後要因の分類項目としては，

Edward, Hawkins らの提唱している SHELL モデル10) を参考に,「計画不良 (Software)」と機器 ·工具不備 


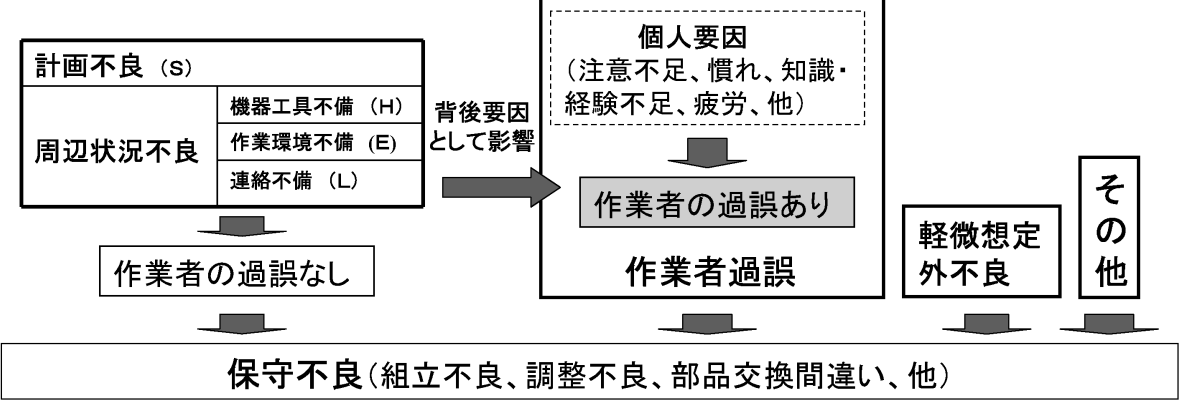

\begin{tabular}{|c|c|c|c|c|c|}
\hline $\begin{array}{l}\text { 小分類 } \\
\text { 項目 }\end{array}$ & $\begin{array}{c}\text { 計画不良 } \\
\text { (S) }\end{array}$ & 作業者過誤 & $\begin{array}{c}\text { 周辺状況不良 } \\
(H, E, L)\end{array}$ & 軽微想定外不良 & その他 \\
\hline r-ス1 & $\bullet$ & & & & \\
\hline ケ-ス2 & $\bullet$ & $\bullet$ & & & \\
\hline ケース3 & $\bullet$ & $\bullet$ & $\bullet$ & & \\
\hline$r-24$ & & $\bullet$ & $\bullet$ & & \\
\hline ケ-ス5 & & $\bullet$ & & & \\
\hline r-26 & $\bullet$ & & $\bullet$ & & \\
\hline ร-ス7 & & & $\bullet$ & & \\
\hline ケ-ス8 & & & & 0 & \\
\hline$r-29$ & & & & & 0 \\
\hline
\end{tabular}

(作業者過誤はその背後要因 $(S, H, E, L)$ との因果関係を付ける)

第 2 図保守不良に打ける作業者過䛊と背後要因の関連付け

\begin{tabular}{|c|c|c|c|}
\hline \multirow[b]{2}{*}{ 原 因 } & 設備不良 & 運用不良 & 外部要因 \\
\hline & $\begin{array}{l}\text { ·設計不良（建設時、機器取替時） } \\
\text { · 製造不良（建設時、機器取替時） } \\
\text { • 施工不良（建設時） } \\
\text { · 経年劣化（腐食、疲労、他） } \\
\text { · 偶発故障 }\end{array}$ & 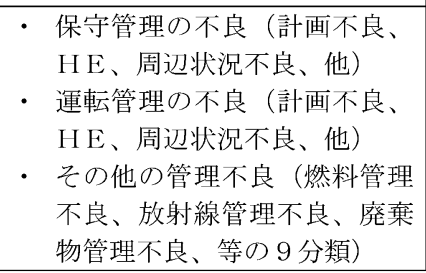 & $\begin{array}{l}\text { 想定内 (落雷等の異常気象、 } \\
\text { 送電線事故、等) } \\
\text { ・想定外 (妨害行為、テロ })\end{array}$ \\
\hline \multicolumn{4}{|l|}{ により、 } \\
\hline 直接原因 & \multicolumn{3}{|c|}{$\begin{array}{l}\text { · 設備の機械的故障（変形、破損、破断、漏洩、閉塞、機能低下、溶接欠陥、亀裂、等） } \\
\text { · 設備の電気的故障（短絡、過熱、過電圧、誤信号、等） } \\
\text { · 系統の機能低下（圧力低下、流量低下、等）や異常挙動（振動、ウオータハンマ、等） } \\
\text { • 火災、爆発、冠水 }\end{array}$} \\
\hline \multicolumn{4}{|l|}{ が発生し、 } \\
\hline 不具合事象 & \multicolumn{3}{|c|}{ 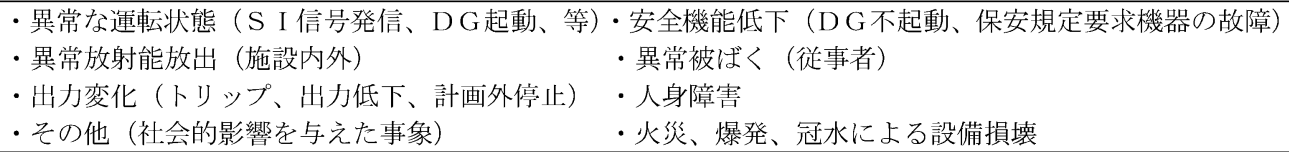 } \\
\hline
\end{tabular}

という不具合を起こした。

第 3 図 原因・直接原因 $\cdot$ 不具合事象の関係

(Hardware)，作業環境不備 (Environment)，上司·同僚 の指示・連絡不備 (Liveware)ををとめた「周辺状況不良」 の 2 項目にして分類時の簡便化を図った。

また，通常入手する不具合情報では背後要因を遡れるま での詳細情報はないが，重大な事故で詳細記述がある場合 には，背後要因をさらに遡って分析することによって，人 的過誤が起こる組織風土や安全文化との関連性を追求して 行くことが可能となる。

\section{（７）「軽微想定外不良」の設定}

不具合には新知見や予測されるが現実的には対応策が取 り難いものが含まれている。これら事後対応とならざるを
得ない不可抗力的な原因を「軽微想定外不良」として区分 することにした。この分類項目に属する原因に対しては現 実的な予防対策が取り難く防止が困難である。ここに分類 される不具合は, 規制当局, マスコミ, 公衆の理解が得ら れる範囲でなければならず, 関係者とのリスクコミュニ ケーションを取りながら対応して行く必要がある。

\section{（８）根本原因の究明過程としての原因分類}

不具合というのは, 異常放射能放出, 出力変化, 人身傷 害，等の不利益がでた事象であり，その事象に至った直接 の原因である設備の機械的・電気的故障, 系統の機能低 下，火災，爆発，等が状況として報告されている。しかし 


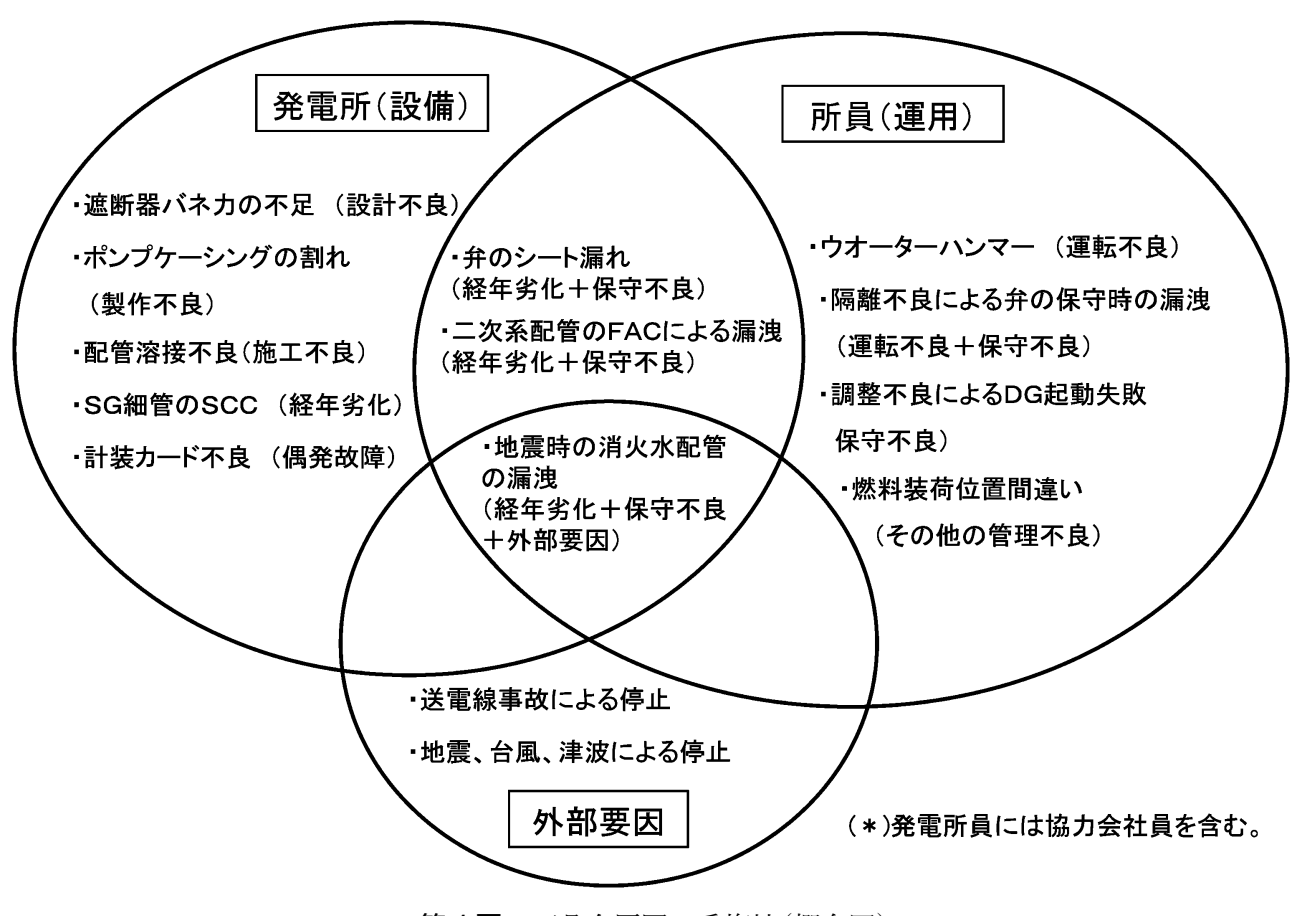

第 4 図 不具合原因の重複性 (概念図)

ながら, 重要なのは不具合の直接原因ではなく, 直接原因 を遡って究明される根本原因が重要である。根本原因は費 やす時間・費用・人員により最終的に究明される原因レべ ルが異なってくる。第 3 表の新原因分類表は通常究明さ れる程度の原因レベルを小分類項目として示したものであ るが，小分類項目の人的過誤や周辺状況不良などの背後要 因をさらに展開して検討することによって根本原因が自然 と究明されるように考慮されており，根本原因を体系的に 検討する際に役立つと考える。報告書に記載されている原 因・直接原因 ·不具合事象の一般的な関係を第 3 図に示 し，今回の原因分類項目の位置付けを明確にする。

\section{（9）事象に含まれる原因は重複計上}

1 つの不具合の原因は 1 つと限らず複数の原因が影響し ている場合が少なくない。この場合は，含まれるすべての 原因をコード付けする必要がある。不具合原因の重複性を 模式図で示すと第 4 図のようになる。傾向分析の際に は，主原因だけで整理する方法と含まれる原因を重複計上 して整理する方法があり，原因を主原因のみで整理する方 法は事象数と原因数が一致する点が便利であるが，原因を 重複計上する方が発生した不具合をすべて抽出したことに なり実態を把握することができる。両者は分析のねらいに 応じて使い分ける必要がある。

\section{INSS 旧原因分類法からの改善点}

本研究で開発した新分類項目をINSS の旧分類項目と比 較したものを第 5 図に示すが，以下の点で改善されてい ることが判る。

（1） 大分類 - 中分類 - 小分類に展開して細分化されてお
(旧)

\begin{tabular}{|c|c|c|c|}
\hline 設備不良(設計不良) & 設計不良 & 設計者過誤、他 & \multirow{5}{*}{ 設 備 } \\
\hline 設備不良 (製作不良) & 製造不良 & 製造者過誤、他 & \\
\hline 設備不良（施工不良） & 施工不良 & 施工者過誤、他 & \\
\hline 設備不良 & 経年劣化 & 2分類 & \\
\hline 設備劣化 & 偶発故障 & 1分類 & \\
\hline 疲労損傷 & \multirow{4}{*}{ 保守不良 } & \multirow{4}{*}{\begin{tabular}{|l|} 
計画不良 \\
作業者過誤 \\
周辺状況不良 \\
軽微想定外不良 \\
その他 \\
\end{tabular}} & \multirow{10}{*}{ 運 用 } \\
\hline 保守不良 & & & \\
\hline 保守不良(マニュアル不備) & & & \\
\hline 保守不良 (人的三ス) & & & \\
\hline 運転不良 & \multirow[t]{4}{*}{ 運転不良 } & \multirow{4}{*}{$\begin{array}{l}\text { 計画不良 } \\
\text { 操作者過誤 } \\
\text { 周辺状況不良 } \\
\text { 軽微想定外不良 } \\
\text { その他 }\end{array}$} & \\
\hline 運転不良(マニュアル不備) & & & \\
\hline 運転不良 (人的ミス) & & & \\
\hline 管理不良 & & & \\
\hline 外的要因(地檽、等6分類) & その他の & 燃料管理不良 & \\
\hline 外的要因 (テ口) & 管理不良 & 等 8分類 & \\
\hline & 外部要因 & 想定内、想定外 & 外部要因 \\
\hline
\end{tabular}

第 5 図 原因分類の新旧比較

り体系的である。

（2）設備面には「経年劣化」と「偶発事象」が新設され た。

（3）運用面は「運転不良」·「保守不良」・「その他の管理 不良」の 3 区分々簡略化されたが，「運転不良」と 「保守不良」は小分類で「計画不良」「操作者過誤(作 業者過誤 $) 」$ ・周辺状況不良」・「軽微想定外不良」. 「その他」の 5 項目に細分化されて展開する階層構造 となっている。

（4）設計段階から運転保守段階に至るまでの各段階にお ける人的過誤が「設計者過䛊」・製造者過誤」・「施工 者過䛊」「操作者過䛊」「「作業者過誤」として明確に 
区分されている。

\section{IV. 新原因分類法の適用例}

\section{1. 海外の不具合事例への適用例}

INSS では新原因分類法を2006年入手の不具合情報から 正式に適用しているので，実際に新分類法を使用した傾向 分析例はまだ少ない11)。2005年入手の海外原子力発電所 の不具合について，旧分類法で分類した結果を第 $\mathbf{6}$ 図 に，新分類法を適用した場合の分類結果を第 7 図に示 す。また，2006年入手の海外不具合を新分類法で分類し た結果を第 8 図と第 9 図に示す。旧分類法に較べて新分 類法を適用することによって次のような点が初めて明らか になった。

(1) 発電所の不具合全体の約 6 割は運用面の不具合で あり，設置された設備の不具合よりも，設備の運転・ 保守といった運用面の不具合割合の方が多いことが判 る。

（2）「経年劣化」は不具合全体の 1 割強である。

(3) 運用面の不具合では「保守不良」が最も多く約 6 割を占め，「運転不良」よりも防止対策が重要である

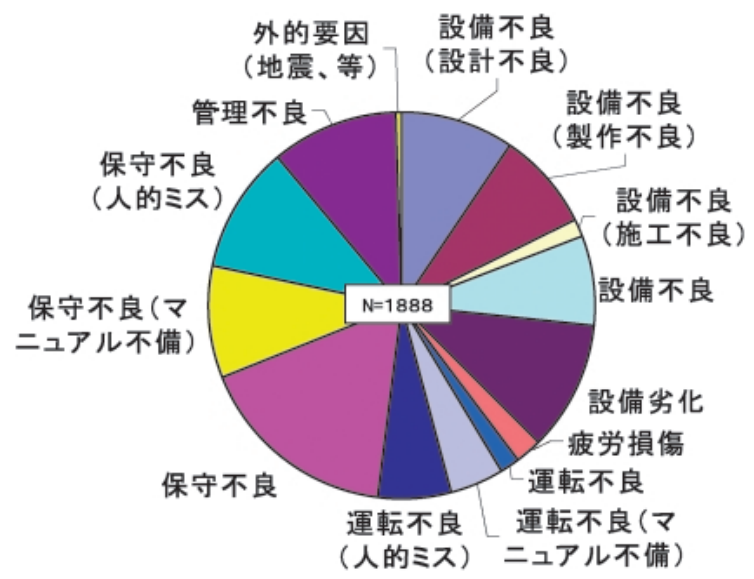

\section{運転不良}

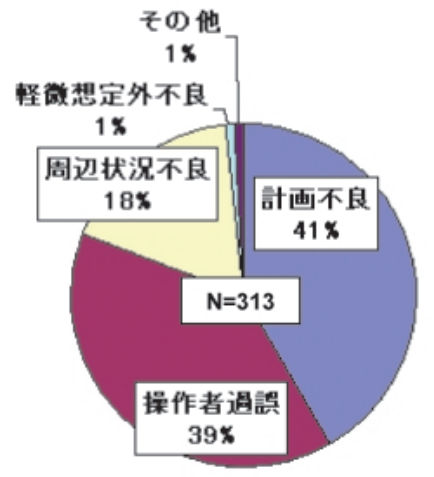

ことが判る。

（4）「保守不良」では，計画段階の「計画不良」が最も

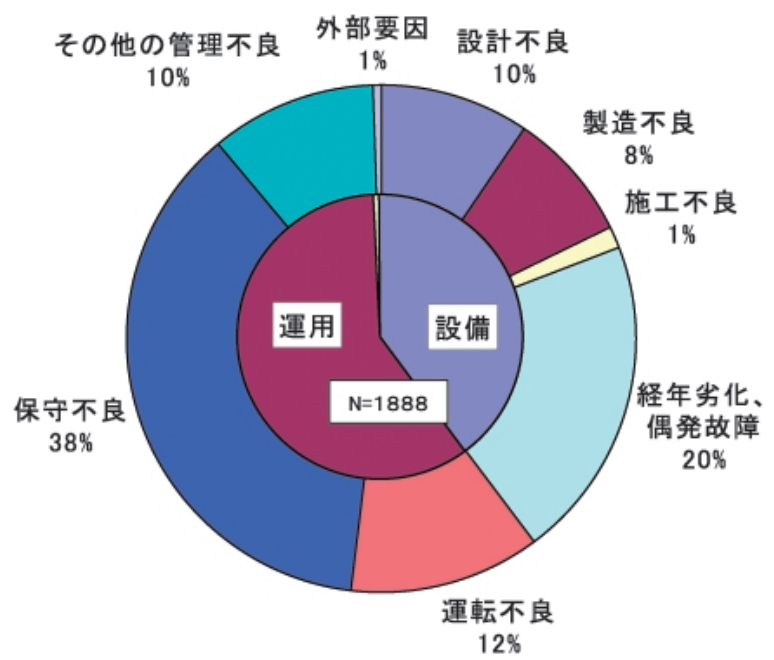

第 7 図 新原因分類法による海外原子力発電所の不具合原因 (2005年，大分類と中分類）

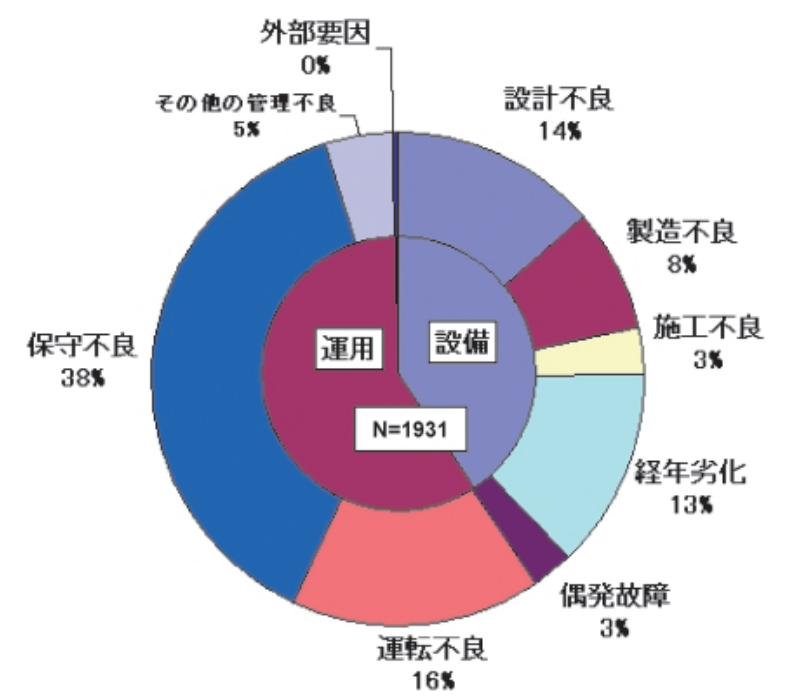

第 8 図 新原因分類法による海外原子力発電所の不具合原因 (2006年，大分類と中分類)

第 9 図 新原因分類法による海外不具合原因 (運転不良と保守不良)の内訳 (2006年，小分類) 


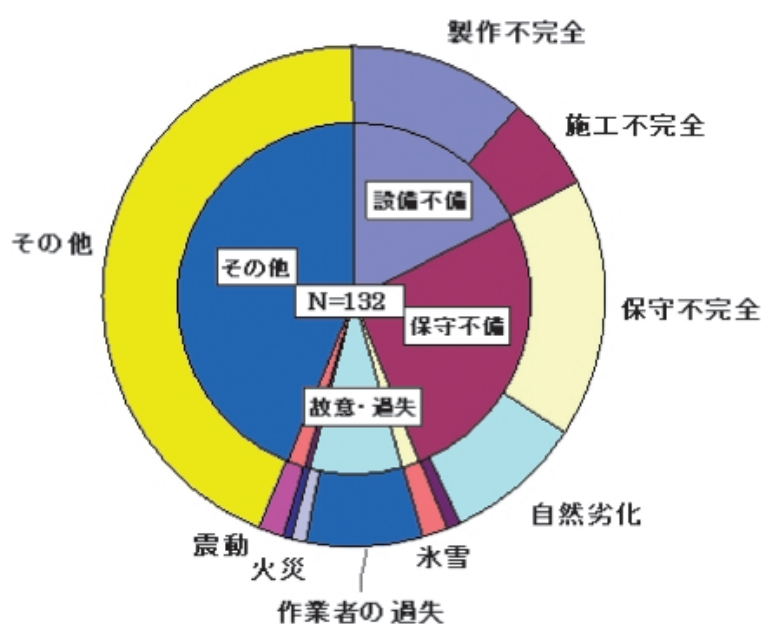

第10図 ニューシア掲載の国内原子力発電所の不具合原因 (2005 年度,「保全品質情報」以上の不具合全体)

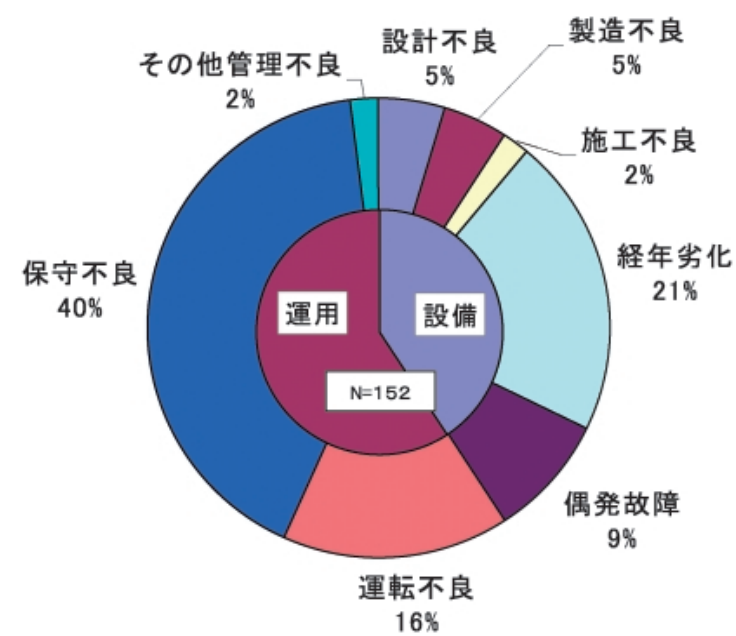

第11図 新原因分類法による国内原子力発電所の不具合原因 (2005年，大分類と中分類)

多く約 5 割を占める。

（5）「保守不良」では，実施段階での人的過誤である 「作業者過䛊」が約 3 割を占める。

\section{2. 国内の不具合事例への適用例}

電気保安年報の原因分類法を準用しているこューシア揭 載の国内不具合 (2005年度, 「保全品質情報」以上)の原因 分類結果を第10図に示すが，次のような問題点がある。

（1）「その他」が 4 割以上を占めて抢り，原因が適切に 分類し切れてない。

(2) 前述 II-2-( 1 ) 項に示したように，「設備不備」に 設計不良の分類項目がない，「作業者の過失」はある が「運転員の過失」に相当する分類項目がない，設備 の不具合と人間運用の不具合が区分されておらず「保 守不備・保守不完全」に人的過誤による不具合が含ま れているのか人的過䛊はすべて「故意・過失」の「作 業者の過失」で整理するのか判然としない。

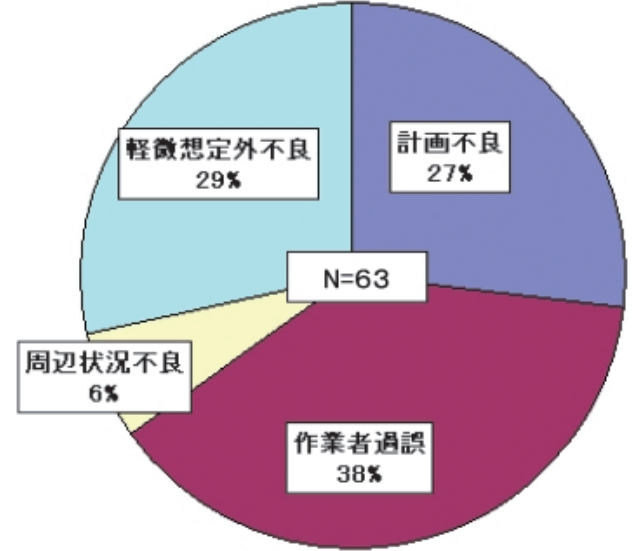

第12図 新原因分類法による国内不具合原因(保守不良)の内訳 （2005年，小分類）

（3）全体としての分類体系が判かり難い。

一方，新原因分類法を適用した場合の分類結果を第11

図および第12図に示すが，上記の問題点は解消され，新 分類法によって分類体系が判りやすくなり, 従来の分類法 では明確でなかった次の点が判明した。

（1）国内も海外と同様に，運用面の不具合が全体の約 6 割を占めている。

（2）運用面の不具合の中では「保守不良」が最も多く約 7 割を占め, 海外よりも若干割合は多いが，国内も海 外と同じ傾向を示している。

（3）「保守不良」を展開(小分類）した第12図から，「保 守不良」では「作業者過䛊」が最も多く約 4 割を占 め, 国内では「作業者過䛊」防止が改善対象として重 要であることが判る。

なお，第10図と第11図で原因総数に差違があるのは， 同じ不具合を対象にしていても，分類項目に相違がある場 合重複計上した際に差違が生じるためである。

\section{V. 考察}

本研究では, 原子力発電所の不具合に対する新原因分類 法とその適用例を示したが，新分類法は，原子力発電所の 不具合対策の方向として, 設備面よりも運用面に重点を置 く，運転管理面よりも保守管理面に重点を置く，人的過誤 に重点を置くことの必要性を明示しており，対策の対象を 絞り込むのに適した分類法であることが判る。新分類法に よって対策の必要性が示された作業者過誤については，こ の新分類法に基づき分類された作業者過䛊と背後要因の関 連性を分析して人的過誤の防止を図る研究12,13) が進められ て抢り，この新分類法が人的過誤の分析に役立っている。 さらに，この新分類法による人的過誤や背後要因の分析を 深く進めることによって, 近年問題となっている組織要因 や安全文化の問題点も整理して行くことが可能と考える。

なお，原因分類法や分析結果は分野ごとにそれぞれ相違 しており，航空機の分野でボーイング社がまとめた商業用 
ジェット機の事故原因14)をみると，乗組員不良が55\% で，保守不良は $3 \%$ に過ぎない。このように産業や分野に よって分析結果に大きな差異があるので，今後は，異なる 産業分野間の分析方法や特性の比較検討も行い原子力分野 の原因分類法の改善につなげて行くことも必要と考える。

\section{VI. 結 言}

本研究では, 原子力発電所の不具合の原因分類法とし て，次のような特長をもつ新しい原因分類法を提案した。

(1) 発電所の管理者の視点に立った分類とした。

(2) 発電所の不具合を「設備」と「運用」に大別した。

（3）設備面には「経年劣化」を設定した。

(4) 運用面は発電所の各種管理で分類した。

（5）人的過誤を「設計者過誤」·製造者過䛊」·「施工者 過䛊」「操作者過䛊」·「作業者過䛊」と細分化した。

(6) 人的過誤の背後要因 (計画不良, 機器 · 工具不備, 作業環境不備，指示・連絡不備）を分析できる体系と した。

（7）「軽微想定外不良」を設定した。

（8）根本原因の究明過程としての原因分類になる。

続いて，今回提案した新原因分類法を国内外の原子力発 電所の不具合に適用した分類結果からは, 次のような不具 合傾向のあることが判明した。

(1) 不具合全体の約 6 割は運用面の不具合が占める。

(2)「経年劣化」は不具合全体の 1 割強を占める。

(3) 運用面の不具合の中では「保守不良」が最も多く6〜 7 割を占める。

（4）海外の「保守不良」では，計画段階の「計画不良」 が最も多く約 5 割を占め，実施段階の「作業者過䛊」 が約 3 割を占める。

（5）国内の「保守不良」では，「作業者過誤」が最も多 く約 4 割を占める。

（6）不具合原因の構成割合に若干の差違はあるが国内と 海外で不具合発生傾向に大きな相違はない。

この傾向分析の結果からは，不具合を低減するために は，運用面での保守管理の充実，特に作業者過誤の防止が 重要であることが判る。

筆者らはこの新原因分類法を適用して今後もさらに国内 外の不具合の傾向分析を進めて行く予定であるが，本研究 で示した新原因分類方法は汎用性のある原因分類法である と考えるので，原子力発電所の不具合だけに適用されるも
のではなく一般産業でも広く利用されて不具合防止に資す ることを期待する。

本研究を進めるに当たっては, INSSの原子力情報研究 プロジェクトの千葉吾郎, 高川健一, 伏見康之, 藤井 登, 嶋田善夫, 島田宏樹各氏の助言や不具合分析結果を利 用させて頂きました。また, 岡山大学の五福教授には本論 文を執筆する際にご助言を頂きました。ここに記して深く 感謝の意を表します。

$$
\text { 一参考文献一 }
$$

1）宮崎孝正, 佐藤正啓, 高川健一, 他, “海外原子力発電所で 発生した不具合事象の傾向分析 (2003年), ” 日本保全学会第 1 回学術講演会要旨集, 83-88 (2004).

2）宮崎孝正，佐藤正啓，高川健一，他，“海外原子力発電所の 不具合事象の発生傾向, ”日本原子力学会「2005年春の年会」 要旨集, B21 (2005).

3）佐藤正啓，宮崎孝正，“米国原子力発電所の出力増強に伴う 不具合事象分析, ” 日本原子力学会「2005年秋の大会」予稿 集, M1 (2005).

4）宮崎孝正, 佐藤正啓, 高川健一, 他, “海外原子力発電所の 不具合事象の発生傾向 (2004年), ” 日本原子力学会「2005年 秋の大会」予稿集, M2 (2005).

5）原子力安全 - 保安院編, 電気関係報告規則の解説, 社日本電 気協会, 89-133 (2005).

6）原子力施設情報公開ライブラリー(http://www.nucia.jp/), (中)日本原子力技術協会.

7) NRC, Rates of Initiating Events at U.S. Nuclear Power Plant: 1987-1995, NUREG/CR-5750 (1998).

8）原子力安全 - 保安院編, 原子力施設運転管理年報, 独原子力 安全基盤機構.

9）トラブル情報データベース (http://www.jnes.go.jp/)，独原 子力安全基盤機構.

10) Frank H. Hawkins, Human Factors in Flight, 2nd Ed., Avebury Technica (1993).

11）島田宏樹, “原子力発電所の不具合事象の傾向分析; (2)米国 の遮断器不具合, ”日本原子力学会「2006年秋の大会」予稿 集, C28 (2006).

12）宮崎孝正, 高川健一, 五福明夫, “原子力発電所の不具合事 象の人的過誤の分析一(1)新しい人的過誤分析手法一, ” 日本 原子力学会「2007年春の年会」要旨集, D46 (2007).

13）高川健一, 宮崎孝正, 五福明夫, “原子力発電所の不具合事 象の人的過誤の分析-(2)国内の不具合事象の分析結果, ”日 本原子力学会「2007年春の年会」要旨集, D47 (2007).

14) BOEING, Statistical Summary of Commercial Jet Airplane Accidents 1959-2005, (http://www.boeing.com/news/techissues/pdf/statsum.pdf) 